\title{
Sectoral Growth and Developments within the Financial Sector: Evidence from Selected Sectors in Turkey
}

\author{
Ahmet Cemil Borucu ${ }^{1} \&$ Veysel Ulusoy ${ }^{1}$ \\ ${ }^{1}$ Department of Financial Economics, Yeditepe University, İstanbul, Turkey \\ Correspondence: Prof. Dr. Veysel Ulusoy, Department of Financial Economics, Yeditepe University, İstanbul, \\ Turkey. Tel: 90-216-578-0000. E-mail: vulusoy@yeditepe.edu.tr
}

Received: October 11, 2012

Accepted: October 30, $2012 \quad$ Online Published: November 16, 2012

doi:10.5539/ijef.v4n12p252

URL: http://dx.doi.org/10.5539/ijef.v4n12p252

\begin{abstract}
This paper examines the effects of developments in the financial sector upon real sector growth based on data from 2003 to 2011 in Turkey. During this period, following a severe banking crisis, banks changed their operating model from channeling funds to finance government debt to increasing and maintaining their loan portfolio to business entities and real persons. Moreover, strict regulations were imposed by the newly established banking regulation authority. The results of the study are in line with existing growth literature that argues that financial deepening is positively related with growth. In addition, we find that sector-based non-performing loans are negatively related to real sector growth, whereas net interest margins are positively related to it. These results are also in line with expectations.
\end{abstract}

Keywords: financial sector, economic growth, panel data, GMM; Turkey

JEL Classification: G21; O16

\section{Introduction}

Although it is quite a popular topic within economics, the empirical literature on the finance-growth nexus has not yet come to terms with a number of fundamental issues such as i) whether financial developments drive macroeconomic growth or vice versa and ii) what are the generally accepted determinants of growth. The reason why this issue attracts so much attention stems from the fact that the results of these empirical studies have significant influence upon how policy makers devise their economic programs. Those who support the idea that financial development is important for economic growth argue that, as the level of sophistication and depth increases for financial intermediaries, economic development and technological innovation further accelerate by mobilizing savings, allocating capital, evaluating projects, exerting corporate control, managing risks, and monitoring projects. (Note 1) On the other hand, some researchers assert that financial development is a consequence of economic growth, where the latter increases the demand for more sophisticated financial instruments, which in turn leads to growth in the former. (Note 2)

This paper examines the effects of developments in the financial sector upon real sector growth, based on data from 2003 to 2011 in Turkey. During this period, following a severe banking crisis, banks changed their operating model from channeling funds to finance government debt to increasing and maintaining their loan portfolio to business entities and real persons. Moreover, strict regulations were imposed by newly established banking regulation authorities. The results of the study are in line with existing growth literature that financial deepening is positively related with growth. In addition, we find that sector-based non-performing loans (NPL) are negatively related to real sector growth, whereas net interest margins (NIM) are positively related to it. These results are also in line with expectations given that, as a rational institution, banks will be reluctant to lend to sectors in which repayment problems exist. Moreover, banks will attempt to channel more funds to increase their loan portfolio during an economic climate that enables them to increase their net interest margin. In Turkey, financial sector institutions primarily include banks; therefore, our study focuses mainly on banking sector data relationships with real sector growth. The aim of this paper is to contribute to growth literature by investigating the interaction at sectoral level. In addition, it explores the validity of factors specific to the financial sector in their relation to real sector growth. 


\section{Developments within the Finance Sector in Turkey, 1998-2011}

An economic liberalization program was launched during the 1980s in Turkey that ultimately significantly impacted financial and real sector growth (i.e., deregulation of interest rates, transformation of the exchange-rate regime, introduction of government securities auctions, expansion of export incentives, and import liberalization) However, prevailing high inflation and budget deficits brought in increased government borrowing with ever-increasing interest rates, which forced banks to borrow from financial institutions abroad and make arbitrage profits by lending to the government. Even the 1994 financial crisis, which saw the local currency devalued, did not prevent the banking sector or big industrial companies from choosing to lend to the government. This situation in turn intensified competition within the banking sector, but not to attract deposits so as to increase loans to customers' portfolios, but rather to continue increasing the value of government bonds on their balance sheets. This unsustainable vicious circle broke in 2001, when a severe financial crisis occurred, apparently triggered by political instability. Following this crisis, the banking sector went through a consolidation phase; the banks that survived were closely supervised and monitored by a separate independent regulatory institution (before the crisis, banking sector oversight was performed by two separate institutions: the Undersecretariat of the Treasury and the Central Bank of Turkey; following the 2001 financial crisis, a separate independent body, the Banking Supervision and Regulation Agency, was established). The 2001 crisis was a milestone for the financial sector in Turkey, not only because of the aforementioned developments, but also because the banking sector started competing on the basis of expanding loan-to-customer portfolios rather than solely channeling funds into government bonds. Even when the global financial crisis began to affect Turkey, the banking sector continued its efforts to maintain loan portfolios rather than to reduce them. All of the changes mentioned herein can be summarized succinctly by the loan/deposit ratio, which was around $40 \%$ at the end of the 1990s and beginning of the new century but rose to $88 \%$ during 2011 .

Table 1 provides an overview of such developments. A decrease in the number of banks represented the consolidation of the sector following the 2001 banking crisis. The financial depth measure (i.e., DEPTH) is comparatively higher than credit (i.e., CREDIT) in the pre-crisis period, but the gap steadily closed in the subsequent period, revealing that banks were channeling funds into the private sector rather than financing government debt. This is supported by the fact that the loans/deposits ratio increased substantially during this period.

Table 1. Selected financial sector developments in Turkey, 1998-2011

\begin{tabular}{lllll}
\hline YEAR & NUMBER OF BANKS & CREDIT & DEPTH & LOAN/DEPOSITS \\
\hline 1998 & 75 & 0.17 & 0.33 & 0.51 \\
1999 & 81 & 0.16 & 0.43 & 0.37 \\
2000 & 79 & 0.16 & 0.39 & 0.42 \\
2001 & 61 & 0.14 & 0.46 & 0.31 \\
2002 & 54 & 0.10 & 0.39 & 0.25 \\
2003 & 50 & 0.12 & 0.34 & 0.34 \\
2004 & 48 & 0.14 & 0.34 & 0.43 \\
2005 & 47 & 0.19 & 0.36 & 0.52 \\
2006 & 46 & 0.23 & 0.38 & 0.60 \\
2007 & 46 & 0.26 & 0.39 & 0.67 \\
2008 & 45 & 0.28 & 0.44 & 0.65 \\
2009 & 45 & 0.31 & 0.49 & 0.65 \\
2010 & 45 & 0.39 & 0.50 & 0.78 \\
2011 & 44 & 0.58 & 0.66 & 0.88 \\
\hline
\end{tabular}

Note: CREDIT is "Total Loans/GDP, DEPTH is "Total Deposits/GDP", and LOAN/DEPOSITS is "Total Loans/Total Deposits." All ratios are calculated for commercial banks only.

Thus, following the aftermath of the 2001 financial crisis, a financial sector made up primarily of commercial banks changed its operating model from financing government debt to channeling funds toward customer loans.

\section{Methodology}

In order to address estimation problems confronted during finance growth empirical studies, the instrumental variables estimation method within a GMM framework was used. This approach enables us to take into 
consideration the issue of endogeneity of regressors, which causes bias and inconsistency in OLS and the fixed effects estimator. Moreover, we are able to exploit panel data so as to increase the precision of estimation in an area where data for a limited period is available. In addition, we are able to use a dynamic model setting by implementing a dynamic panel data approach. Finally, by using fixed effects in the panel setting, the heterogeneity of cross-sectional units is also taken into account.

To specify our model and explain assumptions accordingly:

$$
Y_{i, t}=a_{i}+\beta X_{i, t}+\gamma Y_{i, t-1}+u_{i, t}
$$

where $Y_{i, t}$ is quarterly GDP growth on a sectoral basis, $Y_{i, t-1}$ is lagged sectoral growth, $X_{i, t}$ is all other explanatory variables thought to affect dependent variables, $a_{i}$ is unobserved sector-specific effects, and $u_{i, t}$ is an error term. The subscript $i$ denotes selected sectors for which the effects of the financial sector developments are examined. The subscript $t$ denotes the quarterly timeframe for which the study is conducted.

In order to eliminate unobserved sector-specific effects that cause correlation between individual specific effects and lagged dependent variables, we first examined the differences:

$$
\Delta Y_{i, t}=\beta \Delta X_{i, t}+\gamma \Delta Y_{i, t-1}+\Delta u_{i, t}
$$

which represents the first difference of the variable under consideration.

Yet with this transformation we introduce a correlation between the dependent variable and error term in equation (2). Thus, we subsequently introduce conditions for the GMM dynamic panel estimator, which basically asserts that the error term is not serially correlated with the regressors. (Note 3)

$$
\begin{gathered}
\mathrm{E}\left(Y_{i, t-s}, \Delta u_{i, t}\right)=0 \text { for } s>=2, t=3, \ldots, \mathrm{T} \\
\mathrm{E}\left(X_{i, t-s}, \Delta u_{i, t}\right)=0 \text { for } s>=2, t=3, \ldots, \mathrm{T}
\end{gathered}
$$

Instrument validity is tested using the Sargan test/Hansen J-statistic with the null hypothesis that the instruments are exogenous - in other words, not correlated with residuals.

In order to investigate the effects of developments within the financial sector on selected private sector growth from 2003 to 2011 in Turkey, the model of the form (2) is estimated with the explanatory variables $X_{\mathrm{i}, \mathrm{t}}$, which include a measure of financial depth CREDIT along with selected other variables thought to affect sectoral growth, such as measures of profitability where data are available to calculate on a sectoral basis (NIM = Net Interest Margin, NPL $=$ Non-performing loans, NPLGEN $=$ NPL generation, INTREV_NPL $=$ Net interest revenue over NPL) as well as a measure of external availability of funds from abroad (ABROADDBANKLOANS $=$ loans obtained by commercial banks from financial institutions abroad), a measure of value of publicly traded banks (XUMALI = Istanbul Stock Exchange Financial Intermediary Index), and a measure of alternative lending (INTERBANKRATE $=$ interest rates on the Turkish interbank market).

\section{Data}

The data set includes seven selected sectors for 2003 to 2011, and data make up a balanced panel. Selected sectors for this study are [1] agriculture, hunting, and forestry; [2] mining and quarrying; [3] manufacturing; [4] electricity, gas, and water supply; [5] construction; [6] wholesale and retail trade; and [7] transport, storage, and communication. The dependent variable is quarterly growth in seven sectors (GROWTH), measured by sectoral GDP figures with constant 1998 prices.

The explanatory variables are as follows: GROWTH-1 is the lagged value of sectoral GDP quarterly growth. CREDIT is the quarter-end balance of commercial bank loans granted to selected sectors/GDP. NIM is the quarterly net interest income/quarter-end balance of commercial bank loans granted to selected sectors. NPL is the non-performing loan balance at quarter end/(non-performing + performing loans). NPLGEN is incremental NPL during the quarter/(average performing + non-performing loans). INTREV_NPL is net interest revenue/NPL amount. ABROADBANKLOANS is the balance of loans granted to selected sectors/loans obtained from financial institutions abroad. XUMALI is the log difference of the financial sector stock market index value. INTERBANKRATE is the log difference of interest rates in the interbank market. Data were obtained from the Turkish Institute of Statistics (TUIK), the Central Bank of the Republic of Turkey (CBTR), and the Banking Supervision and Regulation Agency (BRSA).

Table 2 provides descriptive statistics while Table 3 provides a correlation matrix for dependent and explanatory variables. 
Table 2. Descriptive statistics of variables

\begin{tabular}{llllllllll}
\hline & GROWTH & NIM & NPL CREDIT & $\begin{array}{l}\text { INTREV } \\
\text { NPL }\end{array}$ & NPLGEN & $\begin{array}{l}\text { TCMBON } \\
\text { INT }\end{array}$ & $\begin{array}{l}\text { ABR_MALI } \\
\text { BANK } \\
\text { LOANS }\end{array}$ \\
\hline Mean & 5.59 & 0.04 & 0.04 & 1.44 & 0.01 & -0.0003 & 0.20 & $57,162.90$ & 20,017 \\
Median & 7.02 & 0.03 & 0.03 & 1.29 & 0.00 & 0.0002 & 0.19 & $54,609.09$ & 23,119 \\
Maximum & 22.05 & 0.08 & 0.19 & 4.78 & 0.18 & 0.0169 & 0.51 & $102,173.74$ & 53,924 \\
Minimum & -26.36 & 0.02 & 0.00 & 0.12 & 0.00 & -0.0826 & 0.09 & $11,221.19$ & 14 \\
Std. Dev. & 8.37 & 0.02 & 0.03 & 0.95 & 0.02 & 0.0083 & 0.10 & $25,872.89$ & 13,491 \\
Observations & 245 & 245 & 245 & 245 & 245 & 245 & 245 & 245 & 245 \\
\hline
\end{tabular}

Table 3. Correlation matrix between variables

\begin{tabular}{|c|c|c|c|c|c|c|c|c|c|}
\hline & $\begin{array}{l}\text { TCMB } \\
\text { ONINT }\end{array}$ & $\begin{array}{l}\text { XU } \\
\text { MALI }\end{array}$ & CREDIT & $\begin{array}{l}\text { ABROADB } \\
\text { ANK } \\
\text { LOANS } \\
\end{array}$ & GROWTH & $\begin{array}{l}\text { INTREV } \\
\text { NPL }\end{array}$ & NIM & NPL & $\begin{array}{l}\text { NPL } \\
\text { GEN }\end{array}$ \\
\hline $\begin{array}{l}\text { TCMB } \\
\text { ONINT }\end{array}$ & 1.00 & & & & & & & & \\
\hline XU_MALI & -0.81 & 1.00 & & & & & & & \\
\hline $\begin{array}{l}\text { CREDIT } \\
\text { ABROAD }\end{array}$ & -0.47 & 0.46 & 1.00 & & & & & & \\
\hline $\begin{array}{l}\text { BANK } \\
\text { LOANS }\end{array}$ & -0.55 & 0.57 & 0.64 & 1.00 & & & & & \\
\hline GROWTH & 0.03 & 0.12 & -0.12 & 0.03 & 1.00 & & & & \\
\hline $\begin{array}{l}\text { INTREV } \\
\text { NPL }\end{array}$ & 0.00 & 0.01 & 0.22 & 0.09 & 0.04 & 1.00 & & & \\
\hline NIM & 0.65 & -0.75 & -0.45 & -0.60 & 0.07 & -0.01 & 1.00 & & \\
\hline NPL & 0.48 & -0.42 & -0.33 & -0.45 & 0.07 & -0.42 & 0.42 & 1.00 & \\
\hline NPLGEN & -0.35 & 0.21 & 0.12 & 0.13 & -0.23 & 0.01 & -0.29 & -0.32 & 1.00 \\
\hline
\end{tabular}

Note: High correlation exists between XU_MALI and TCMBONINT and NIM.

\section{Empirical Results}

An empirical study was conducted using a dynamic panel analysis by estimating equations (2) with GMM using optimally lagged instruments. (Note 4) The following table outlines the results of the study.

Table 4. Regression Results

\begin{tabular}{ll}
\hline Variable & Coefficient \\
\hline $\mathrm{Y}_{\mathrm{t}-1}$ & $0.82^{*}$ \\
& $(0.12)$ \\
$\mathrm{NPL}$ & $-25.64^{* * *}$ \\
& $(13.95)$ \\
$\mathrm{NIM}$ & $303.11^{*}$ \\
& $(17.82)$ \\
Credit & $2.97 *$ \\
& $(0.36)$ \\
\hline Sargan Test & 4.05 \\
Wald Test & 33.68 \\
Joint significance & \\
\hline
\end{tabular}

$* * *$ Significant at the 1 percent level. ** Significant at the 5 percent level. * Significant at the 10 percent level.

Non-performing loans are strongly and, as expected, negatively related to sectoral growth. One would not expect banks to continue to channel funds on sectors where loan quality is deteriorating and/or sectors which have 
increasing problematic loans to grow sustainably. Net interest margin is positive and significantly related to sectoral growth for the analyzed period. This is line with expectations since primary driving force of bank profits is to maintain a healthy interest spread between loans and deposits and thus continue to grow their loan portfolio in times where such lending rates prevail. Credit/GDP as a measure of financial depth is positively and significantly related to sectoral growth. Although the level of significance is not as high as non-performing loans and net interest margin. Coefficient of lagged sectoral growth is also positive and significant as expected. All of the estimated coefficient signs are as expected. However, other explanatory variables are not significantly related, and various lags of NPLGEN and INTREV_NPL have been used as instruments within the model.

The Sargan test for the validity of instruments, where the null hypothesis is that instruments used are not correlated with error terms, is not rejected. Moreover, the Wald test for joint significance coefficients, where the null hypothesis is that all coefficients equal zero, is significantly rejected.

\section{Concluding Remarks}

This empirical study investigated the relation between sectoral growth and developments in the financial sector in Turkey from 2003 to 2011. The dynamic panel model was specified, and an instrumental variable approach was used within a GMM framework. One of the results is that financial deepening is positively related with sectoral growth, which is in line with existing studies. However, Ardiç and Damar (2006) examined similar effects for provincial growth from 1996 to 2001 and concluded that financial development is negatively related with growth. Yet when we understand that during this period banks in Turkey were channeling domestic resources to the government in order to cover up budget deficits, the results make sense. After the banking crisis in 2001, banks in Turkey underwent a significant restoration along with all economic actors; thereafter, the focus of business was to expand the loan portfolio to real persons and companies. Our study examined the period following the crisis and thus confirmed these opinions as well. In addition, we concluded that, as a profitability measure, the net interest margin is positively related to sectoral growth while the measure for loss (i.e., non-performing loans) is negatively related to it, which is in line with expectations.

\section{References}

Ardic, O. P., \& Damar, H. E. (2007). Financial Sector Deepening and Economic Growth: Evidence from Turkey. Topics in Middle Eastern and North African Economies, IX.

Arellano, M., \& Bond, S. (1991). Some Tests of Specification for Panel Data: Monte Carlo evidence and an application to employment equations. Review of Economic Studies, 58, 277-97. http://dx.doi.org/10.2307/2297968

Beck, T. (2002). Industry Growth and Capital Allocation: Does Having a Market- or Bank-Based System Matter? Journal of Financial Economics, 147-180. http://dx.doi.org/10.1016/S0304-405X(02)00074-0

King, R., \& Levine, R. (1993). Finance and Growth: Schumpeter Might Be Right. Quarterly Journal of Economics, 108, 717-37. http://dx.doi.org/10.2307/2118406

Levine, R. (2004). Finance and Growth: Theory and Evidence. NBER Working Paper, (No. 10766).

\section{Notes}

Note 1. See for example King and Levine (1993) and Beck and Levine (2002).

Note 2. Levine (2004) provides a review of the arguments both for and against.

Note 3. See Arellano and Bond (1991) for details.

Note 4. Dynamic panel estimation was done using Dynamic Panel Data (DPD) estimator on Eviews. 